\title{
A Longitudinal Categorization of US Airline Industry via Dynamic Stock Return Method
}

\author{
Seong-Ho Cho \\ School of Business Administration, Hongik University, Seoul, Korea \\ Email address: \\ shcho11@hongik.ac.kr
}

To cite this article:

Seong-Ho Cho. A Longitudinal Categorization of US Airline Industry via Dynamic Stock Return Method. International Journal of Economics, Finance and Management Sciences. Vol. 6, No. 2, 2018, pp. 35-42. doi: 10.11648/j.ijefm.20180602.11

Received: February 20, 2018; Accepted: March 11, 2018; Published: April 2, 2018

\begin{abstract}
In this exploratory paper, the dynamic stock return method (DSRM) initially proposed as an effective and replicable method by [14], [4], [5], [6] is deliberately applied to the US airline industry over the period from 1979 to 1992 (14 years). The longitudinal categorization or strategic group (SG) results from the DSRM show good face validity. They are consistent with the industry's fact-based historical progress. We also observe that the operational measures such as market share or productivity tend to support the grouping results. Furthermore, the results of 15- and 7-year analysis of relative closeness of stock responsive movements between two representative airline firms (American and Hawaiian airlines, respectively) could be inferred that the SGs derived from the DSRM are valid and robust over a longer time span. We conclude that the DSRM could be a good alternative instrument for the longitudinal study of industry substructure.
\end{abstract}

Keywords: Categorization, Strategic Group, Niche, Industry Substructure, Cluster, US Airline Industry, Longitudinal Structural Dynamics, Longitudinal Study

\section{Introduction}

Although several empirical attempts have been made to analyze longitudinal dynamics of strategic groups (SGs) or distinctive categories within an industry [7]; [10], [11]; [12]; [8]; [3]; [15]; [16], their methods have been attacked by their known limitations such as statistical artifact and subjectivity [1]; [4], [5], [6]; [3]; [16]. In fact, the arbitrary choice of some critical strategic behaviors is not likely to produce objective and replicable categories or SG groupings. While the longitudinal analysis is required to capture and reflect any dynamic changes over time in critical strategic behaviors among member firms, furthermore, the conventional methods appear to fail to accommodate them properly [1]; [6]; [3]; [16]. Specifically, in the conventional methods it may not be easy to reconfigure persuasively the crucial strategic dimensions across different stable strategic time periods (SSTPs).

In this exploratory paper, the dynamic stock return method (DSRM) initially proposed as an effective and replicable method by [14], [4], [5], [6] is deliberately applied to the US airline industry over the period from 1979 to 1992 (14 years). There are three reasons for this. First, the US airline firms are doing single business due to regulatory requirement. Second, the industry's historical progress is well documented especially post to the critical event of its deregulation in 1978. Third, since deregulation the US airline industry has been very competitive and variant players have tried to survive in their own ways. Therefore, there could be various categories, SGs or niches within the industry.

In order to check the face validity, the SG clustering results derived from the DSRM are referenced to the industry's historical progress over the 14 years of time period. As for the post analysis to see whether the categories found are supported, the operational measures such as market share and productivity are analyzed. As a case study of two representative airline firms (American and Hawaiian Airlines), their longitudinal relative closeness in their stock movements is measured over 15 and 7 years, respectively (due to data availability). The statistical results of 15- and 7year analysis of relative closeness between two airlines could be inferred as the categories or SGs derived from the DSRM are valid and robust over a longer time span.

The remaining sections are presented as follows: Section 2 describes the sample data and outlines the method. Results are discussed in section 3. Discussions and conclusions are 
presented in section 4 .

\section{Method}

\subsection{Sample: US Airline Industry}

The sample firms represent all the firms with SIC designation of 4511 or 4512 during the study period between 1979 and 1992. The sample of 30 airline firms is highly specialized in the airline business mainly because of legal constraints (although Worldcorp Inc. is obviously not an airline company, we decide to include it in the sample for the test purpose). The airline industry is particularly chosen because the industry's historical progress is well documented post to its deregulation in 1978. The sample firms are listed in the New York or American Stock Exchanges and have complete stock returns of one year or 50 weeks over the sample period from 1979 to 1992 in the University of Chicago's Center for Research in Security Prices (CRSP) data tapes. The sample period of this study includes 171month periods (1979-1992) after the signing of the Airline Deregulation Act in October 1978 when business environment became increasingly less regulated.

With gradual deregulation of the domestic US air transportation beginning in 1978, and the reduced involvement of the Civil Aeronautics Board in the industry, airlines have adopted quite different growth strategies and have adjusted their structures according to the new environment. Thus, we expect to observe industry-wide structural changes due to environmental changes in the years following the deregulation decision. For example, United Airlines has extended its route structure to nationwide resulting in significant changes in its route structure by mid1979 (Business Week, 1980). In 1978, Alaska Airlines served only 10 Alaskan cities and Seattle, but shortly after the Deregulation, Alaska extended operations into California.
The first half of 1980s could be described as a period of tense competition amongst incumbents. Firms in the industry have explored various possibilities for survival in face of fierce competition and uncertainty. While new firms entered into the industry seeking for niches (i.e. geographical), existing firms (incumbents) tried to outperform though creative services and products. However, the successfully invented services and products were easily replicated by major competitors. An example would be the frequent fliers' mileage program launched first by American Airlines in 1981. In the same year, United counters with its own program, followed by TWA, Delta, Northwest, and Continental. During the second half of the 1980s, on the other hand, there were a significant number of mergers and acquisitions in the airline industry. In 1986, the acquisition activities were especially significant. It can be referred as a period of consolidation from diversified variation during the first half of 1980s.

\subsection{Variables}

As suggested by [6], the variables used for clustering are the correlation coefficients of stock return residuals for each firm in the sample. Once the weekly stock return residuals (WARs) after eliminating systematic risk are obtained via market model, they are correlated between the sample firms each week to produce the correlation coefficient matrix between firms. Therefore, the between-firm correlation coefficient or $r_{i j}$ is a measure that summarizes the closeness of WAR movements between firm $\mathrm{i}$ and firm $\mathrm{j}$ over the time span.

The variables are regarded to capture magnitudes and directions of instaneous stock return movements reflecting disturbances over each sample year (s). In the sample of 30 firms, a complete set of 50,100, 150, 250 weekly stock returns in the sample period from 1979 to 1992 are used for study.

\subsection{Cluster Identification}

Table 1. List of Sample firms $(N=30)$.

\begin{tabular}{|c|c|c|}
\hline COMPANY NAME & BEG-END* & SIC \\
\hline AIRCAL INC & $850102-870429$ & 4511 \\
\hline AMERICAN AIR LINES INC & $620702-921231$ & 4511 \\
\hline ALASKA AIRGROUP INC & $620702-921231$ & 4511 \\
\hline ALOHA AIRLINES INC & $791214-861226$ & 4511 \\
\hline BRANIFF INT'L CORP & $620702-820527$ & 4511 \\
\hline BRITISH AIRWAYS PLC & $870211-921231$ & 4511 \\
\hline CONTINENTAL ARLNS HLDGS & $780406-920320$ & 4512 \\
\hline EASTERN AIRLINES INC & $620702-861123$ & 4511 \\
\hline FRONTIER AIRLINES INC & $640415-851121$ & 4511 \\
\hline HAWAIIAN AIRLINES INC & $740523-921231$ & 4511 \\
\hline JET AMERICAN ARLNS INC & $841003-861226$ & 4511 \\
\hline KLM ROYAL DUTCH ARLNS & $620702-921231$ & 4511 \\
\hline MGM GRAND INC & $891213-921231$ & 4512 \\
\hline MIDWAY AIRLINES INC & $880609-911001$ & 4512 \\
\hline OZARK AIRLINES INC & $670508-860915$ & 4511 \\
\hline PAN AM CORP & $620702-910925$ & 4511 \\
\hline PIEDMONT AVIATION INC & $780925-871104$ & 4511 \\
\hline REPUBLIC AIRLINES INC & $730522-860812$ & 4511 \\
\hline
\end{tabular}




\begin{tabular}{lll}
\hline COMPANY NAME & BEG-END* & SIC \\
\hline SEABOARD WORLD ARLNS INC & $620702-800930$ & 4511 \\
SOUTHWEST AIRLINES CO & $751024-921231$ & 4511 \\
TIGER INT'L INC & $620702-890215$ & 4511 \\
TRANS WORLD ARLNS INC & $830303-881024$ & 4511 \\
UNITED AIR LINES CORP & $620702-921231$ & 4512 \\
US AIR GROUP INC & $620702-921231$ & 4511 \\
W T C INT'L NV & $700709-870903$ & 4511 \\
WESTAIR HOLDING INC & $881025-920529$ & 4512 \\
WESTERN AIRLINES INC & $620702-861218$ & 4511 \\
WORLDCORP INC & $670424-921231$ & 4511 \\
\hline
\end{tabular}

* BEG-END is the beginning and ending dates of CRSP's available data. For instance, AirCal's CRSP data is available from January 2, 1985 through April 29, 1987.

As suggested by the DSRM, Ward's minimum variance method is used for cluster analysis due to its superior performance. In order to evaluate its robustness against outliers, the outliers exceeding the $1,3,5,7$ percent limits were respectively deleted. Ward's method produced the same SG results up to 5 percent deletions. ${ }^{1}$ As also proposed by the DSRM, we apply stopping rules of both Pseudo F statistic [2] and Pseudo $\mathrm{T}^{2}$ statistic [9].

\subsection{Longitudinal SSTPS in the US Airline Industry}

An SSTP is defined as time periods of homogeneity with regard to competitive strategic behavior [10]. As suggested by [6], in the DSRM an SSTP could be determined and identified by comparing pooled and unpooled clustering results over time. If the grouping structure of 1-year window, say, 1979 (unpooled) is similar with that of 2-year window or 1979-1980 (pooled), we use 1979-1980 as an SSTP. Otherwise, 1979 is regarded as a separate SSTP. As suggested by Cho [6], Bartlett's test and Hoteling's $\mathrm{T}^{2}$ test are used to check whether the pooled and unpooled clustering matrices are similar.

In our sample of US airline firms in 1979-1992, SSTP ${ }_{1979-83,}$ SSTP $_{1984-88,}$ SSTP $1988-92$, and SSTP ${ }_{1981-85}$ are further analyzed to examine the evolutionary paths of SGs or niches within the industry. It is well known that the industry has gone through volatile structural changes including fierce competition due to regulatory deregulation (the first half of 1980s) and industrywide mergers and acquisitions for consolidation (peak at 1986). During the period 1979-1983, the average number of firms in the industry was 16 which are 4 less than that of 1981-1985. In 1988-1992, there were only 10 airline firms in the industry after all. Around 1986, its industry-wide consolidation has been made through mergers and acquisitions. A comparison of the mean vectors using Hotelling's $\mathrm{T}^{2}$ tests and variance-covariance matrices using Bartlett's test shows statistically significant differences among the SSTP ${ }_{1979-83}$, SSTP ${ }_{1984-88,}$ SSTP $_{1988-92, \text { and }}$ SSTP ${ }_{1981-85}$. In Table 2, the longitudinal strategic groups in SSTP 1979-83, SSTP 1984-88, SSTP 1988-92, and SSTP ${ }_{1981-85}$ are respectively presented.

1 With 1, 3, 5\% deletions of outliers, the SG results are robust and classification power increases. Although they becomes less robust with $7 \%$ deletion, but the SG outcome is the same.

\subsection{Post Analysis}

As for post analysis, some representative firms are chosen from the evolutionarily persistent three strategic groups, namely, domestic leading group (American, United, Delta), foreign leading group (British, KLM), and niche group (Alaska, Hawaiian). Although the group memberships already show a high level of face validity, we would like to examine each group's characteristics in terms of operational measures such as revenue, net income, and productivity. Further, this paper attempts to explore to measure the closeness of the evolutionary paths of two firms within an industry by analyzing the closeness of stock return movements as shown in the Method section.

In our exploratory paper, American Airlines and Hawaiian Airlines will be examined as representative firms mainly because they are distinguishable from the stand point of face validity. In order to analyze the longitudinal movements of other airline companies (i.e. Delta) relative to a representative firm, say, American Airlines (see table 6), we develop a grand summary statistic which summarizes stock movements between an airline company (i.e. Delta) and a representative firm (i.e. American) over the period of 1978 through 1992 or 15 years. A grand summary statistic is an average of annual coefficients for the 15 years, which measure the closeness of stock return movements over 50 weeks or one year. We use the average of annual coefficients for 15 years as a proxy for the closeness of the evolutionary paths of two firms. Similarly, Table 7 shows the result of the grand summary statistic of Hawaiian Airlines with respect to other airlines including Aloha.

\section{Results}

\subsection{The Nature of the Clusters}

According to the DSRM, there are 3 SSTPs in the 19791992 time horizon in the US airline industry, say, SSTP 1979 ${ }_{83}$, SSTP ${ }_{1984-88}$, SSTP ${ }_{1988-92}$ as exhibited in Table 2. These SSTPs appear to confirm the industry's fact-based historical progress as described in section 2.1. 
Table 2. Composition of the Derived Categories or SGs.

\begin{tabular}{|c|c|c|c|c|}
\hline & $1979-83$ & 1984-88 & 1988-92 & 1981-85* \\
\hline I & $\begin{array}{l}\text { AMERICAN AIR LINES INC } \\
\text { UNITED AIR LINES CORP } \\
\text { NORTHWESTERN ARLNS INC } \\
\text { DELTA AIRLINES INC DE } \\
\text { TRANS WORLD ARLNS INC } \\
\text { US AIR GROUP INC }\end{array}$ & $\begin{array}{l}\text { AMERICAN AIR LINES INC } \\
\text { DELTA AIRLINES INC DE } \\
\text { UNITED AIR LINES CORP } \\
\text { US AIR GROUP INC } \\
\text { NORTHWESTERN ARLNS INC }\end{array}$ & $\begin{array}{l}\text { AMERICAN AIR LINES INC } \\
\text { DELTA AIRLINES INC DE } \\
\text { UNITED AIR LINES CORP } \\
\text { SOTHWEST AIRLINES CO } \\
\text { US AIR GROUP INC } \\
\text { ALASKA AIRGROUP INC }\end{array}$ & $\begin{array}{l}\text { AMERICAN AIR LINES INC } \\
\text { UNITED AIR LINES CORP } \\
\text { DELTA AIRLINES DE } \\
\text { US AIR GROUP INC } \\
\text { NORTHWESTERN ARLNS } \\
\text { INC } \\
\text { OZARK AIRLINES INC } \\
\text { PIEDMONT AVIATION INC } \\
\text { TRANS WORLD ARLNS INC } \\
\text { SOUTHWEST AIRLINES CO } \\
\text { ALASKA AIRGROUP INC }\end{array}$ \\
\hline II & $\begin{array}{l}\text { FRONTIER AIRLINES INC } \\
\text { OZARK AIRLINES INC } \\
\text { PIEDMONT AVIATION INC } \\
\text { WESTERN AIRLINES INC } \\
\text { SOUTHWEST AIRLINES CO }\end{array}$ & $\begin{array}{l}\text { ALASKA AIRGROUP INC } \\
\text { SOUTHWEST AIRLINES CO } \\
\text { KLM ROYAL DUTCH ARLNS } \\
\text { PAN AM CORP } \\
\text { TIGER INTL INC }\end{array}$ & $\begin{array}{l}\text { BRITISH AIRWAYS PLC } \\
\text { KLM ROYAL DUTCH ARLNS }\end{array}$ & $\begin{array}{l}\text { EASTERN AIRLINES INC } \\
\text { REPUBLIC AIRLINES INC } \\
\text { PAN AM CORP } \\
\text { WESTERN AIRLINES INC } \\
\text { KLM ROYAL DUTCH ARLNS }\end{array}$ \\
\hline III & $\begin{array}{l}\text { REPUBLIC AIRLINES INC } \\
\text { TIGER INTL INC }\end{array}$ & CONTINENTAL ARLNS HLDGS & & $\begin{array}{l}\text { CONTINENTAL ARLNS } \\
\text { HLDGS } \\
\text { TIGER INTL INC }\end{array}$ \\
\hline IV & W T C INTL NV & & & $\begin{array}{l}\text { ALOHA AIRLINES INC } \\
\text { HAWAIIAN AIRLINES INC }\end{array}$ \\
\hline
\end{tabular}

As shown Table 2, in the SSTP ${ }_{1979-83}$ which represents post 5-year period since 1978's liberalization in the airline industry, the leader group includes American, United, Northwest, Delta, TWA and US Air (Category I). Some nonmarket leaders like Frontier, Ozark, Pedimont, Western and Southwest Airlines are grouped together (Category II), while Tiger and Republic are classified as another group (Category III).

In the consolidating period of 1984-1988 or SSTP ${ }_{1984-88,}$ the leader group becomes more obvious (American, Delta, United, US Air, and Northwest) and the number of firms in the industry decreases from 21 to 12 . Since 1986, mergers and acquisitions have become prevalent in the industry; in 1986, Continental bought People Express and Frontier Airlines, and Delta bought Los Angeles based Western Airlines; Alaska bought Long Beach-based Jet America Airlines and Seattle-based Horizon Air Industry; Northwest acquired Republic Airlines in 1987; American acquired Nashville Eagle Commuter Airlines. This period can be inferred as a consolidating period in which competitors survive through mergers and acquisitions of less competitive airlines (k-type) [13]. By 1987, the number of firms diminishes from 22 to 13.

In SSTP ${ }_{1988-92}$ which is a period post to consolidation, overall industry substructure stays stable. There seem 3 categories or SGs in the industry, namely, domestic leading group (American, Delta, United), foreign leading group (British, KLM), and niche group (Southwest, Alaska). One notable category is the niche group where the newcomers like Southwest and Alaska become successful in their unique ways successfully to serve their own category of consumers like price-sensitive buyers.

SSTP $_{1981-85}$, the categories or SGs in the period of 1981 to 1985 is additionally exhibited in the last column of Table 2 in the hope of detecting possible industry substructure turmoil before the blast of M\&A waves. In the $\mathrm{SSTP}_{1981-85}$, SGs look chaotic after industry liberalization. Significantly, the number of firms competing in the industry has been maximized and thus competition has become more intense. More firms have entered into the airline market which used to be lucrative but restricted. Among the incumbents including market leaders, the competition became fiercer in the fight to increase or maintain market share. For example, American was the first to launch the frequent flyer program in 1981, using the SABRE system to keep track of clients' mileages. However, this successful program was soon replicated by major competitors, and in the same year or 1981, United countered with its own program followed by TWA, Delta, Northwest, and Continental. SSTP ${ }_{1981-85}$, could be inferred as r-type suggested by [13] in which competing firms in the industry explore various possible ways for survival or success under the increasingly competitive and uncertain environment.

Table 3 shows sales volume over the period from 1984 to 1992 for the representative firms from the 3 strategic groups. In terms of average annual revenue, American $(\$ 9,223$ million) and United possess ( $\$ 9,035$ million) the largest market share in the industry followed by Delta $(\$ 6,924$ million), British ( $\$ 6,467$ million), and Northwest $(\$ 5,477$ million). US Air realizes a middle-to-low market share until 1987, but it boosts its market share to an upper middle level afterwards. Comparing the firms in the leader group in the period from 1984-1992 (3rd and 4th Columns in Table 2), American, United, and Delta are consistently in the same group and they stay in the highest hierarchy within the group. Although British Airlines has the 4th largest market share, it has not been grouped into the leader group. In the case of Southwest, although it possesses small market share $(\$ 1,011$ million), it is grouped among the leaders, but in the lowest hierarchy within the group. 
Table 3. Sales of Representative Airlines in 1984-1992.

\begin{tabular}{|c|c|c|c|c|c|c|c|c|c|c|}
\hline & 1984 & 1985 & 1986 & 1987 & 1988 & 1989 & 1990 & 1991 & 1992 & Mean \\
\hline American Airlines & 5,354 & 6,131 & 6,018 & 7,198 & 8,824 & 10,480 & 11,720 & 12,887 & 14,396 & 9,223 \\
\hline United Airlines & 6,218 & 5,306 & 7,119 & 8,305 & 8,982 & 9,794 & 11,037 & 11,663 & 12,890 & 9,035 \\
\hline Delta Airlines & 4,264 & 4,684 & 4,460 & 5,318 & 6,915 & 8,089 & 8,582 & 9,171 & 10,837 & 6,924 \\
\hline Northwest & 2,445 & 2,655 & 3,589 & 5,142 & 5,650 & 6,576 & 7,426 & 7,683 & 8,128 & 5,477 \\
\hline US Air & 1,630 & 1,765 & 1,835 & 3,001 & 5,707 & 6,252 & 6,559 & 6,514 & 6,686 & 4,439 \\
\hline Continental Airlines, Inc. & 1,372 & 1,944 & 4,407 & 8,626 & 8,552 & 6,650 & 6,184 & 5,487 & 5,494 & 5,413 \\
\hline Trans World Airlines & 3,657 & 3,867 & 3,185 & 4,056 & 4,361 & 4,507 & 4,606 & 3,660 & 3,634 & 3,948 \\
\hline KLM & 1,618 & 2,310 & 2,637 & 3,002 & 2,792 & 3,386 & 3,426 & 4,290 & 4,549 & 3,112 \\
\hline Southwest Airlines & 536 & 680 & 769 & 778 & 860 & 1,058 & 1,237 & 1,379 & 1,803 & 1,011 \\
\hline Alaska Airlines & 362 & 433 & 468 & 710 & 814 & 917 & 1,047 & 1,104 & 1,115 & 774 \\
\hline
\end{tabular}

Table 4 displays net incomes over the period of 1984 to 1992 for selected firms. On average, British (\$279 million), American (\$137 million), and Delta (\$110 million) realize the largest net income in the industry. Southwest $(\$ 53$ million) stays profitable even in the 1990s when most domestic firms are not doing well. Although United and Northwest achieve the largest market share in revenues, United and Northwest realize average net income (loss) of
$\$ 57$ million and (\$213 million), respectively. Like other major domestic airlines, they suffered big losses since 1990 . Comparing the firms in groups in the period of 1988-1992 (Table 2), British is obviously separated from American and Delta although it achieves comparable revenue and net income. On the other hand, United, Northwest, and Southwest are grouped together with American and Delta, although in the lowest hierarchy within the group.

Table 4. Net Incomes of Representative Airlines.

\begin{tabular}{|c|c|c|c|c|c|c|c|c|c|c|}
\hline & 1984 & 1985 & 1986 & 1987 & 1988 & 1989 & 1990 & 1991 & 1992 & Mean \\
\hline American Airlines & 234 & 346 & 279 & 198 & 477 & 455 & $(40)$ & $(240)$ & $(475)$ & 137 \\
\hline United Airlines & 282 & (49) & 12 & (4) & 600 & 324 & 94 & $(332)$ & (417) & 57 \\
\hline Delta Airlines & 176 & 259 & 47 & 264 & 307 & 461 & 303 & $(324)$ & $(506)$ & 110 \\
\hline Northwest & 56 & 73 & 77 & 103 & 135 & 75 & $(465)$ & $(488)$ & $(1482)$ & $(213)$ \\
\hline US Air & 122 & 117 & 98 & 195 & 165 & $(63)$ & $(454)$ & $(305)$ & $(601)$ & $(81)$ \\
\hline Continental Airlines, Inc. & 28 & 49 & 42 & $(466)$ & (719) & (908) & (2403) & $(306)$ & $(125)$ & $(534)$ \\
\hline Trans World Airlines & 30 & (208) & $(106)$ & 45 & 250 & (287) & $(274)$ & (11) & (318) & $(98)$ \\
\hline KLM & 84 & 122 & 148 & 169 & 175 & 178 & $(330)$ & 68 & $(311)$ & 32 \\
\hline Southwest Airlines & 50 & 47 & 50 & 20 & 58 & 75 & 51 & 33 & 97 & 53 \\
\hline Alaska Airlines & 24 & 26 & 18 & 13 & 37 & 43 & 16 & 10 & $(80)$ & 12 \\
\hline
\end{tabular}

In order to see productivity in conjunction with net incomes, Table 5 presents Income as\% of sales over the period of 1984 to 1992. Southwest (5.7\%) and British (4.6\%) are the most productive followed by Alaska (2.5\%), American (2.4\%), and Delta $(2.3 \%)$. Other major domestic firms in the leader group show low to moderate productivity or less than $1 \%$. Comparing the firms in groups in the period of 1988-1992 (Table 2), British is grouped together with KLM (2.0\%), and is separated from Southwest.

Table 5. \% Net Incomes of Revenues for Representative Airlines.

\begin{tabular}{|c|c|c|c|c|c|c|c|c|c|c|}
\hline & 1984 & 1985 & 1986 & 1987 & 1988 & 1989 & 1990 & 1991 & 1992 & Mean \\
\hline Southwest Airlines & $9.3 \%$ & $6.9 \%$ & $6.5 \%$ & $2.6 \%$ & $6.7 \%$ & $7.1 \%$ & $4.1 \%$ & $2.4 \%$ & $5.4 \%$ & $5.7 \%$ \\
\hline British Airways PLC & & $5.9 \%$ & $6.2 \%$ & $4.5 \%$ & $4.0 \%$ & $4.1 \%$ & $5.1 \%$ & $1.9 \%$ & $4.9 \%$ & $4.6 \%$ \\
\hline Alaska Airlines & $6.6 \%$ & $6.0 \%$ & $3.8 \%$ & $1.9 \%$ & $4.6 \%$ & $4.7 \%$ & $1.6 \%$ & $0.9 \%$ & $-7.2 \%$ & $2.5 \%$ \\
\hline American airlines & $4.4 \%$ & $5.6 \%$ & $4.6 \%$ & $2.8 \%$ & $5.4 \%$ & $4.3 \%$ & $-0.3 \%$ & $-1.9 \%$ & $-3.3 \%$ & $2.4 \%$ \\
\hline Delta Airlines & $4.1 \%$ & $5.5 \%$ & $1.1 \%$ & $5.0 \%$ & $4.4 \%$ & $5.7 \%$ & $3.5 \%$ & $-3.5 \%$ & $-4.7 \%$ & $2.3 \%$ \\
\hline KLM & $5.2 \%$ & $5.3 \%$ & $5.6 \%$ & $5.6 \%$ & $6.3 \%$ & $5.3 \%$ & $-9.6 \%$ & $1.6 \%$ & $-6.8 \%$ & $2.0 \%$ \\
\hline United Airlines & $4.5 \%$ & $-0.9 \%$ & $0.2 \%$ & $0.0 \%$ & $6.7 \%$ & $3.3 \%$ & $0.9 \%$ & $-2.8 \%$ & $-3.2 \%$ & $0.9 \%$ \\
\hline Northwest & $2.3 \%$ & $2.7 \%$ & $2.1 \%$ & $2.0 \%$ & $2.4 \%$ & $1.1 \%$ & $-6.3 \%$ & $-6.4 \%$ & $-18.2 \%$ & $-2.0 \%$ \\
\hline Trans World Airlines & $0.8 \%$ & $-5.4 \%$ & $-3.3 \%$ & $1.1 \%$ & $5.7 \%$ & $-6.4 \%$ & $-5.9 \%$ & $-0.3 \%$ & $-8.8 \%$ & $-2.5 \%$ \\
\hline Continental Airlines, Inc. & $2.0 \%$ & $2.5 \%$ & $1.0 \%$ & $-5.4 \%$ & $-8.4 \%$ & $-13.7 \%$ & $-38.9 \%$ & $-5.6 \%$ & $-2.3 \%$ & $-7.6 \%$ \\
\hline
\end{tabular}

\subsection{Relative Closeness of Evolutionary Paths}

The closeness of the evolutionary paths of other airline firms relative to an anchor representative firm in the industry (American or Hawaiian Airlines) is examined over the 1978-
92 time periods. Table 6 presents the longitudinal relative movements of stock returns of airline firms from the perspective of American Airlines. The coefficients in the table or points in the graph represent summary correlation coefficients between a firm and American Airlines over that 
year. For example, 0.0887 in the first cell of the table is the correlation coefficient of stock returns between American Airlines and Alaska Airlines in 1978 (50 weeks). The coefficient is regarded as a measurement which summarizes closeness of stock return movements over 50 weeks or one year. The last column in the table represents the average of the 15 annual coefficients. It can be interpreted as a grand summary statistic which summarizes stock movements between a firm and American Airlines over the period of 1978 through 1992 or 15 years.

Table 6. Summary Correlation Coefficients for Relative Closeness from the perspective of American Airlines (15 years).

\begin{tabular}{|c|c|c|c|c|c|c|c|c|}
\hline & 1978 & 1979 & 1980 & 1981 & 1982 & 1983 & 1984 & 1985 \\
\hline \multicolumn{9}{|l|}{ AIRCAL } \\
\hline ALASKA & 0.0887 & & & 0.4717 & 0.0866 & 0.4142 & 0.3264 & 0.1792 \\
\hline ALOHA & & & -0.1513 & 0.2155 & 0.2477 & 0.1759 & 0.1512 & -0.1374 \\
\hline \multicolumn{9}{|l|}{ BRITISH } \\
\hline CONT & 0.4832 & 0.3758 & 0.5362 & 0.2583 & -0.1736 & 0.3686 & 0.2931 & 0.2355 \\
\hline DELTA & 0.4207 & 0.4271 & 0.4443 & 0.4776 & 0.6623 & 0.6626 & 0.7050 & 0.6329 \\
\hline EASTERN & 0.5031 & & 0.5330 & 0.6949 & 0.4034 & 0.3688 & 0.2276 & 0.3918 \\
\hline FRONTIER & 0.4158 & 0.2462 & 0.3213 & 0.4737 & 0.2671 & 0.2550 & 0.2764 & \\
\hline HAWAIIAN & 0.4490 & & 0.2462 & 0.0296 & 0.0175 & 0.2004 & -0.0962 & -0.2272 \\
\hline KLM & & 0.3244 & & 0.1804 & 0.2791 & 0.1944 & 0.1118 & 0.3551 \\
\hline NW & 0.4542 & 0.435 & 0.4813 & 0.5921 & 0.5076 & 0.7233 & 0.6475 & 0.2647 \\
\hline PAN AM & 0.3094 & & 0.3345 & 0.3531 & 0.2819 & 0.3941 & 0.4471 & 0.2115 \\
\hline PIEDMONT & & 0.1757 & 0.1174 & 0.3848 & 0.2353 & 0.3308 & 0.4387 & 0.4542 \\
\hline EPUBLIC & 0.2103 & 0.5812 & 0.3014 & 0.4302 & 0.0583 & 0.2906 & 0.4450 & 0.5276 \\
\hline SOUTHWEST & 0.1020 & 0.0225 & 0.1807 & 0.2860 & 0.3930 & 0.4867 & 0.5196 & 0.3710 \\
\hline TIGER & 0.1813 & 0.3327 & 0.4025 & 0.2580 & 0.0506 & 0.3243 & 0.2176 & 0.2546 \\
\hline TWC & 0.5379 & 0.2251 & 0.5178 & 0.5821 & 0.5950 & 0.5481 & 0.5570 & 0.1541 \\
\hline UNITED & 0.5062 & 0.5459 & 0.7400 & 0.7084 & 0.3909 & 0.7853 & 0.6644 & 0.6405 \\
\hline US AIR & 0.2290 & 0.3845 & 0.5804 & 0.5929 & 0.5471 & 0.7977 & 0.5616 & 0.0879 \\
\hline WORLDCORP & 0.3710 & & 0.2975 & 0.3367 & 0.1224 & 0.2913 & 0.1026 & 0.1661 \\
\hline MAX & 0.5379 & 0.5812 & 0.7400 & 0.7084 & 0.6623 & 0.7977 & 0.7050 & 0.6405 \\
\hline MIN & 0.0887 & 0.0225 & -0.1513 & 0.0296 & -0.1736 & 0.1759 & -0.0962 & -0.2272 \\
\hline MEAN & 0.3508 & 0.3422 & 0.3677 & 0.4070 & 0.2763 & 0.4218 & 0.3665 & 0.2684 \\
\hline STD & 0.1473 & 0.1485 & 0.2056 & 0.1803 & 0.2713 & 0.1966 & 0.2172 & 0.2282 \\
\hline
\end{tabular}

Table 6. Continued.

\begin{tabular}{|c|c|c|c|c|c|c|c|c|}
\hline & 1986 & 1987 & 1988 & 1989 & 1990 & 1991 & 1992 & Mean \\
\hline AIRCAL & -0.0420 & & & & & & & -0.0210 \\
\hline ALASKA & 0.0681 & 0.2210 & 0.1913 & 0.3183 & 0.1516 & 0.1245 & 0.1319 & 0.2135 \\
\hline ALOHA & 0.2764 & & & & & & & 0.1111 \\
\hline BRITISH & & & 0.2767 & -0.3479 & 0.2477 & -0.0060 & -0.0072 & 0.0327 \\
\hline CONT & -0.0745 & 0.3856 & 0.2948 & 0.3337 & 0.0117 & -0.0750 & & 0.2324 \\
\hline DELTA & 0.6026 & 0.5434 & 0.5996 & 0.5237 & 0.7729 & 0.5010 & 0.7178 & 0.5789 \\
\hline EASTERN & & & & & & & & 0.4461 \\
\hline FRONTIER & & & & & & & & 0.3222 \\
\hline HAWAIIAN & 0.1133 & & & & & -0.1641 & & 0.0632 \\
\hline KLM & 0.1858 & 0.2796 & -0.0133 & -0.0555 & 0.2727 & 0.0299 & 0.1752 & 0.1784 \\
\hline NW & 0.6264 & 0.4355 & 0.4499 & & & & & 0.5107 \\
\hline PAN AM & 0.1709 & -0.0079 & 0.1674 & 0.2683 & -0.0427 & & & 0.2406 \\
\hline PIEDMONT & 0.4169 & & & & & & & 0.3192 \\
\hline EPUBLIC & & & & & & & & 0.3531 \\
\hline SOUTHWEST & 0.0636 & 0.4576 & 0.3904 & 0.2533 & 0.1967 & 0.4366 & 0.3682 & 0.3019 \\
\hline TIGER & 0.1232 & 0.0324 & 0.0825 & & & & & 0.1830 \\
\hline TWC & 0.2624 & -0.0315 & & & & & & 0.3978 \\
\hline UNITED & 0.7280 & 0.1496 & 0.4929 & 0.4710 & 0.2328 & 0.7025 & 0.7296 & 0.5659 \\
\hline US AIR & 0.5038 & 0.4015 & 0.2889 & 0.1796 & 0.3155 & 0.4049 & 0.3937 & 0.4179 \\
\hline WORLDCORP & 0.0940 & -0.0076 & -0.0327 & -0.0379 & -0.0179 & -0.1066 & 0.0975 & 0.1197 \\
\hline MAX & 0.7280 & 0.5334 & 0.5996 & 0.5237 & 0.7729 & 0.7025 & 0.7296 & 0.5789 \\
\hline MIN & -0.1232 & -0.0315 & -0.0327 & -0.3479 & -0.0427 & -0.1641 & -0.0072 & 0.0327 \\
\hline MEAN & 0.2610 & 0.2374 & 0.2657 & 0.1907 & 0.2141 & 0.1848 & 0.3258 & 0.2941 \\
\hline STD & 0.2519 & 0.1976 & 0.1982 & 0.2528 & 0.2219 & 0.2860 & 0.2613 & 0.1590 \\
\hline
\end{tabular}

From the perspective of American Airlines, as shown in Table 6, there are three firms, namely Delta, United, and Northwest, whose grand correlation coefficients are greater than 0.5 , namely $0.5789,0.5659$ and 0.5107 , respectively. Considering that it is a summary statistic over the 15 years, their stock returns have co-moved very tightly over the last 15 years. On the other hand, British Airways and KLM have grand correlation coefficients of 0.0327 and 0.1784 , respectively. While their sales volumes (see Table 3 ) and net incomes (Table 4) are near the group of American, Delta, and 
United, nonetheless, the two airlines are clearly distinguishable from the large trunk airlines. Furthermore, American Airlines easily differentiates itself from small regional airlines such as Alaska (grand coefficient of 0.2135), Aloha (0.1111), and Hawaiian (0.0632).

Table 7. Summary Correlation Coefficients for Relative Closeness from the perspective of Hawaiian Airlines (7 years).

\begin{tabular}{|c|c|c|c|c|c|c|c|c|}
\hline & 1980 & 1981 & 1982 & 1983 & 1984 & 1985 & 1986 & Grand Summary \\
\hline AA & 0.2462 & 0.0296 & 0.0175 & 0.2004 & -0.0962 & -0.2272 & 0.1133 & 0.0405 \\
\hline ALASKA & & 0.1802 & -0.0591 & 0.2081 & -0.1344 & 0.179 & -0.2612 & 0.1058 \\
\hline ALOHA & -0.1172 & 0.6318 & 0.3009 & 0.2966 & 0.1809 & 0.1528 & -.5328 & 0.2827 \\
\hline BRANIFF & 0.1542 & -0.2668 & & & & & & $(0.0563)$ \\
\hline CONT & 0.0483 & 0.0325 & 0.0986 & 0.1221 & -0.0605 & -0.3218 & 0.1622 & 0.0116 \\
\hline DELTA & 0.0332 & 0.1382 & 0.0928 & 0.3758 & -0.0159 & 0.1623 & -0.0465 & 0.1057 \\
\hline EASTERN & 0.1202 & 0.2425 & 0.2595 & 0.1332 & -0.0524 & 0.3194 & & 0.1704 \\
\hline KLM & & 0.0911 & 0.2303 & -0.1373 & 0.0847 & 0.0278 & -0.0541 & 0.0404 \\
\hline NW & -0.0882 & 0.1192 & 0.0328 & 0.1948 & 0.0255 & -0.1262 & 0.2544 & 0.0589 \\
\hline OZARK & 0.2239 & 0.096 & 0.197 & 0.1629 & 0.2299 & 0.0089 & & 0.1531 \\
\hline PAN AM & -0.1025 & -0.0351 & 0.0057 & 0.1816 & -0.1528 & -0.0197 & -0.1455 & $(0.0383)$ \\
\hline PIEDMONT & 0.2026 & 0.0056 & 0.1594 & 0.3211 & 0.0052 & -0.0158 & 0.1719 & 0.1214 \\
\hline REPUBLIC & 0.0667 & 0.066 & 0.0563 & 0.3651 & 0.0376 & -0.1237 & & 0.0780 \\
\hline SOUTHWEST & 0.1396 & 0.3176 & 0.2999 & 0.2077 & 0.1648 & -0.0039 & 0.1528 & 0.1826 \\
\hline UNITED & 0.1568 & 0.0985 & -0.0089 & 0.1687 & 0.007 & -0.1119 & 0.3255 & 0.0908 \\
\hline US & 0.165 & 0.0128 & 0.0242 & 0.3044 & 0.0948 & -0.0414 & 0.0394 & 0.0856 \\
\hline WTC & 0.0686 & -0.0015 & -0.023 & -0.344 & 0.1687 & -0.0085 & -0.0485 & $(0.0269)$ \\
\hline WESTERN & -0.0005 & 0.006 & 0.2507 & 0.3387 & -0.0045 & -0.0801 & & 0.0851 \\
\hline WORLDCORP & -0.0048 & 0.098 & 0.1149 & 0.6182 & 0.2846 & 0.0615 & 0.1039 & 0.1823 \\
\hline MAX & 0.2824 & 0.6318 & 0.3009 & 0.6182 & 0.2846 & 0.1790 & 0.5328 & 0.2827 \\
\hline MIN & -0.1172 & -0.2668 & -0.0591 & -0.3440 & -0.1528 & -0.3218 & -0.1455 & -0.0563 \\
\hline MEAN & 0.0826 & 0.0959 & 0.1085 & 0.1763 & 0.0516 & -0.0378 & 0.1184 & 0.0803 \\
\hline STD & 0.1104 & 0.1638 & 0.1159 & 0.2024 & 0.1209 & 0.1353 & 0.1730 & 0.0776 \\
\hline
\end{tabular}

Table 7 presents the longitudinal movements of airline firms from the perspective of Hawaiian Airlines over the period from 1980 through 1986 (stock return data for the Hawaiian Airlines are not available for other years). As shown in Table 7, Aloha Airlines has the highest grand correlation coefficient of 0.2827 . The average of the grand correlation coefficients is 0.0803 . It is much lower than that of American Airlines or 0.2941 (see Table 6). This fact may imply that Hawaiian Airlines is a niche- -pursuing airline company and that their stock returns would be affected (and move) differently from those of major Airlines companies like American, Delta, and United.

\section{Discussion and Conclusion}

In order to fulfill the imperative need to develop an objective and replicable method to analyze longitudinal dynamics of categories or SGs in an industry, in this paper, the DSRM is applied to the US airline industry over the period of 1979 to 1992 just after a significant event of industry deregulation in 1978 . While the validity of derived categories is checked via the documented industry history, the relative closeness of stock movements between two representative firms (American and Hawaiian Airlines) is further analyzed over the 7- and 15-year time period, respectively.

In our particular sample of US airline industry, the clustering results found show a high level of face validity and confirm the industry's fact-based historical progress. As shown in Table 2, during the period of 1979-1985 the number of firms in the industry increases and the industry leader group does not always include only obvious leading firms such as American, Delta, and United. On the other hand, during the period of 1986-1992, the number of firms in the industry decreases to 10 and the industry substructure become very consistent (see 3rd and 4th 4 columns in Table 2). It appears that the industry liberalization has created lower entry barriers to the industry and thus has caused fierce competition among the firms in the industry (r-type). Consequently, less competitive firms become obsolete, and die out. Competitive firms became more competitive through acquiring less competitive firms (k-type). Niche-specific firms who are efficient survive even in the most competitive environment. In the long run, the firms decrease in number, and the competition has become more intense since deregulation. These facts confirm the paradigm of Industrial Organization of Economics that industrial liberalization is better than restricted industry monopoly from the perspective of social welfare because competition drives firms to be efficient.

As exhibited in Table 6, in the longitudinal analysis of relative closeness from the perspective of American Airlines, the stock returns of the leading firms like American, United, Delta, and Northwest have moved together closely over the 15 -year period, their grand correlation coefficients being greater than 0.5 . As far as niche players are concerned as 
exhibited in Table 7, Hawaiian Airlines has the highest grand correlation coefficient of 0.2827 with Aloha Airlines. Considering that it is a summary statistic over the longer time period like 7 or 15 years (ranging from -1 to 1 ), it seems a surprising result.

Based upon the findings above, we draw a conclusion from this study. The DSRM can effectively identify industry SGs or categories even over a very longer period, say, even 14 year time span. Since derived SGs are obtained through a stylized method with market data, the DSRM is likely to be a replicable method, which enables us to analyze longitudinal

dynamics in industry categorization. The evidences from the representative airline industry in 1979-1992 appear to confirm that the longitudinal industry categorization can be done reliably and meaningfully through the DSRM.

The major limitation of the DSRM would be that diversified firms across industries may not be suitable for clustering. In order to empirically find industry subgroups, nonaggregate group common effects should be detected, not aggregate effects. Nonetheless, we believe that the DSRM may resolve meaningful issues in the field of strategy. Future research includes applying the DSRM to conduct a longitudinal analysis over a long-term time horizon over various industries. It would be particularly interesting to look into the locus of groups' or group members' structural moves. Some additionally important issues in this avenue of research would include the following; the relationship between SG membership and its profitability over time; the locus of structural changes; the presence of first-mover or competitive advantages; and the sustainability of these advantages over a long-term period. Some of these future issues could be hopefully resolved by using the DSRM.

\section{Acknowledgements}

SHC would like to thank Bill McKelvey at UCLA for his valuable comments and support for his dissertation from which the article came. SHC also wishes to thank the Hongik University for their research fund for this study (research project NO: P212017).

\section{References}

[1] Barney, J. B., and R. E. Hoskisson (1990), "Strategic groups: Untested assertions and research proposals", Managerial and Decision Economics, 11, pp 187-198.

[2] Calinski, R. B., and J. Harabasz (1974), “A dendrite method for cluster analysis," Communications in Statistics, 3: 1-27.

[3] Cattani, G., J. F. Porac, and H. Thomas (2017), "Categories and Competition", Strategic Management Journal, 38, pp. 6492 .

[4] Cho, S-H (2007), "On the Stock Return Method to Determining Industry Substructure: The Case of Airline, Banking, and Oil Industries,' Journal of Strategic Management, 10:41-70.

[5] Cho, S-H (2011), "Detecting Industry Substructure via Stock Return Method: NASDAQ Electronics Firms", Journal of Strategic Management, 14 (1):77-103.

[6] Cho, S-H (2017), "On the Dynamic Stock Return Method to Analyzing Longitudinal Industry Substructure", Working Paper, Hongik University.

[7] Cool, K., and D. Schendel (1987), "Strategic group formation and performance: The case of the U.S. pharmaceutical industry", Management Science, 33, pp. 1102-1124.

[8] DeSarbo, W. S., R. Grewal, and R. Wang (2009), "Dynamic strategic groups: deriving spatial evolutionary paths", Strategic Management Journal, 30 (13), pp. 1420-1439.

[9] Duda, R. O., and P. E. Hart (1973), Pattern Classification and Scene Analysis, Wiley, New York.

[10] Fiegenbaum, A., and H. Thomas (1993), "Industry and strategic group dynamics: competitive strategy in the insurance industry, 1970-84. Journal of Management Studies, 30 (1): 69-97.

[11] Fiegenbaum, A., and H. Thomas (1995), "Strategic groups as reference groups: Theory, modeling and empirical examination of industry and competitive strategy", Strategic Management Journal, 16 (6), pp. 461-476.

[12] Mas-Ruiz, F., J. Nicholau-Gonzalbez, and F. Ruiz-Moreno (2005), "Asymmetric Rivalry between Strategic Groups", Strategic Management Journal, 26, pp. 713-745.

[13] McKelvey, Bill (1982), Organizational Systematics, University of California, Berkeley, CA.

[14] Ryans A. B., and D. R. Wittink (1985), "Security returns as a basis for estimating the competitive structure in an industry", in H. Thomas and D. Gardner (Eds.), Strategic Marketing and Management, Wiley, New York.

[15] Suarez FF, Grodal S, and A. Gotsopolous (2014), "Perfect timing? Dominant category, dominant design, and the window of opportunity for firm entry". Strategic Management Journal, 36: 437-448.

[16] Vergne J-P and T. Wry (2014) "Categorizing categorization research: review, integration, and future directions". Journal of Management Studies, 51 (1): 56-94. 